\title{
Giant gallstone in the duodenum
}

\author{
Natalie Allen, ${ }^{1}$ Humza Malik, ${ }^{2}$ Stephen Pettit ${ }^{3}$
}

1 Department of General Surgery, BWF Hospitals Trust, Blackpool, UK

${ }^{2}$ Department of Surgery, BWF Hospitals Trust, Blackpool,

Lancs, UK

${ }^{3}$ BWF Hospitals Trust,

Blackpool, UK

\section{Corresponding to}

Natalie Allen,

na60@hotmail.co.uk

Accepted 4 May 2014

\section{CrossMark}

To cite: Allen N, Malik $\mathrm{H}$, Pettit S. BMJ Case Rep Published online: [please include Day Month Year] doi:10.1136/bcr-2014204938

\section{DESCRIPTION}

Mechanical obstruction is a serious and potentially fatal complication of gallstones. We report a case of Bouveret's syndrome where gastric outlet obstruction was caused by a giant gallstone being impacted in the duodenum.

An 80-year-old man presented with a 7-day history of obstructive symptoms and hiccups. Clinical and biochemical assessment showed dehydration with mild epigastric tenderness.

Abdominal X-ray showed an opacity in the right hypochondrium (figure 1). CT scan showed a large gallstone impacted in the duodenum causing gastric outlet obstruction (figure 2). Pneumobilia was evident.

Gastroscopy and stone extraction was attempted, but was unsuccessful, due to the large size of the gallstone which was firmly impacted in the second part of the duodenum. Laparotomy with duodenotomy and gallstone removal was therefore performed (figure 3).

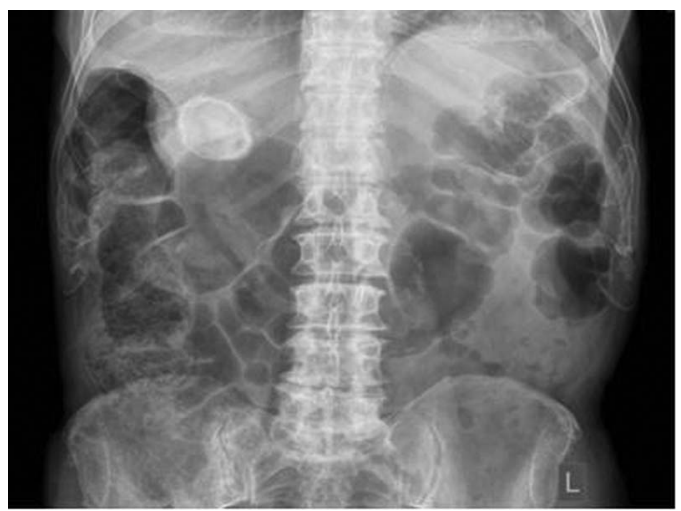

Figure 1 Abdominal X-ray showing a large gallstone in the right hypochondrium.

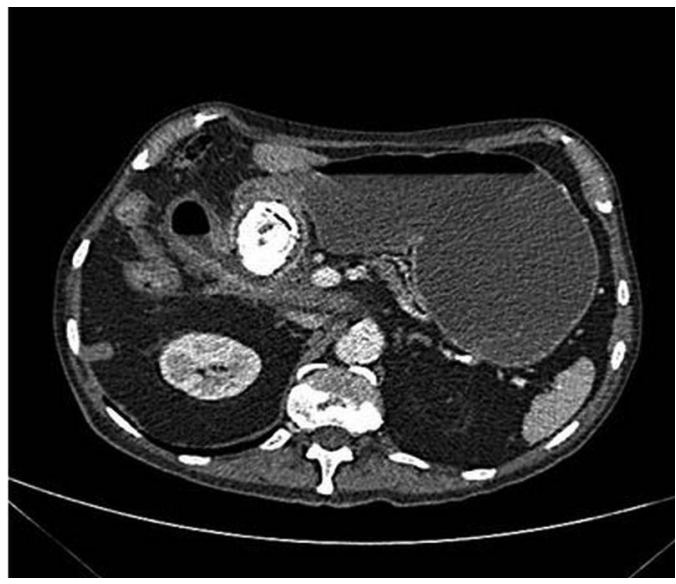

Figure 2 CT scan showing a large gallstone impacted in the second part of the duodenum.

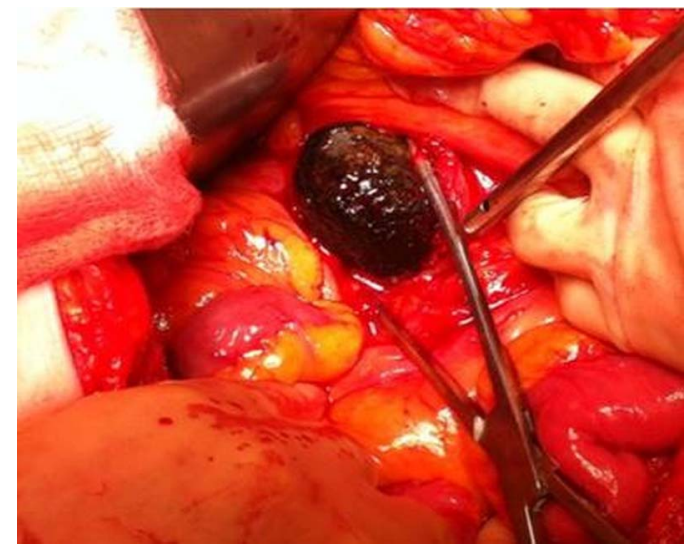

Figure 3 Gallstone being removed from the duodenum at laparotomy.

Dr Erasmus Bartholin first described gallstone ileus in 1654 , reasoning that the gallstone enters the gastrointestinal tract through a biliary enteric fistula, with the terminal ileum being the most frequent site of obstruction. Bouveret's syndrome, first described in 1896 , is where a fistula forms between the gallbladder and the stomach or duodenum allowing a gallstone to migrate into the duodenum causing gastric outlet obstruction. ${ }^{1}$

Abdominal radiographs aid diagnosis but the most common mode of diagnosis is CT scan. The diagnosis is often confirmed with endoscopy. ${ }^{2}$

Published treatment strategies include endoscopy and stone retrieval, laser lithotripsy and extracorporeal shockwave lithotripsy. However, if they fail laparotomy with gallstone removal is the only option. $^{2}$

\section{Learning points}

- Endoscopic strategies may avoid laparotomy in cases of Bouveret's syndrome with a variety of methods that may retrieve giant stones.

- Morbidity of this syndrome is high as it often occurs in patients with multiple comorbidities, who may be nutritionally compromised and unable to tolerate further physiological insults.

Contributors SP was incharge of the care of this patient NA was involved in the patient's care identified the case as a possible case report due to the lessons that could be learnt. All the three authors were involved in the writing up of the case.

Competing interests None.

Patient consent Obtained.

Provenance and peer review Not commissioned; externally peer reviewed. 


\section{Images in...}

\section{REFERENCES}

1 Cappell MS, Davis M. Characterization of Bouveret's syndrome: a comprehensive review of 128 cases. Am J Gastroenterol 2006;101:2139-46.
2 Chick JF, Chauhan NR, Mandell JC, et al. Traffic jam in the duodenum: imaging and pathogenesis of Bouveret syndrome. J Emerg Med 2013;45:e135-7.

Copyright 2014 BMJ Publishing Group. All rights reserved. For permission to reuse any of this content visit http://group.bmj.com/group/rights-licensing/permissions.

BMJ Case Report Fellows may re-use this article for personal use and teaching without any further permission.

Become a Fellow of BMJ Case Reports today and you can:

- Submit as many cases as you like

- Enjoy fast sympathetic peer review and rapid publication of accepted articles

- Access all the published articles

- Re-use any of the published material for personal use and teaching without further permission

For information on Institutional Fellowships contact consortiasales@bmjgroup.com

Visit casereports.bmj.com for more articles like this and to become a Fellow 